https://doi.org/10.25143/socr.13.2019.1.063-075

\title{
Atbildība par nepatiesas informācijas sniegšanu apdrošinātājam apdrošināšanas līguma ietvaros
}

\author{
Jeḷena Alfejeva \\ Rìgas Stradiṇa universitāte, Juridiskā fakultāte, Latvija \\ alfejeva@inbox.lv
}

\section{Kopsavilkums}

Šajā rakstā aplūkots jautājums par atbildību Latvijas apdrošināšanas tiesībās gadījumos, kad apdrošināšanas līguma ietvaros apdrošinātājam tiek sniegta nepatiesa informācija. Tiek sniegts ieskats par apdrošināšanas līguma līdzēju mērḳiem un pienākumiem, raksturota apdrošināšanas līguma būtība tā, lai izprastu iemeslu, kādēḷ apdrošinātājam jāsaṇem informācija par apdrošināmo objektu un riskiem. Apskatīta arī uberrimae fidei principa nozīme apdrošināšanas attiecībās. Vēl šeit ir aplūkots jautājums par atbildības noteikšanu un nepatiesas informācijas sniegšanas sekām. Raksta nobeigumā ir îss kopsavilkums par risinājumiem apdrošināšanas attiecību regulēšanas uzlabošanai Latvijā saistībā ar aplūkotajām problēmām.

Raksta izstrādē galvenokārt tika izmantota analīzes un sintēzes metode, zinātniskās indukcijas un dedukcijas metode, salīdzinošā metode, kā arī novērošana.

Atslēgvārdi: apdrošināšanas līgums, uberrimae fidei, līgumiskā atbildība.

\section{levads}

Kaut arī apdrošināšanas līgums ir privāttiesisks darījums, Latvijas tiesību doktrīnā apdrošinātāja pienākums izmaksāt apdrošināšanas atlīdzỉbu ir izcelts kā publiski nozīmīgs un par to daudz tiek diskutēts tiesiskā regulējuma pilnveidošanas kontekstā $[25,107-117]$.

Savukārt jautājums par apdrošinātāju klientu informācijas izpaušanu pirms līguma noslēgšanas un līguma darbības laikā tiek apskatīts minimāli, galvenokārt uberrimae fidei principa kontekstā, turklāt uzsvaru liekot uz apdrošinātāja pienākumu rīkoties labticīgi. 
Praksē ir bijuši vairāki gadījumi, kuros apdrošinātāja pienākumu neizpilde raisa nopietnas bažas par labticību, tomēr pats uberrimae fidei princips, veidojot attiecīgu legālo doktrīnu, primāri bija domāts klientu informācijas atklāšanai apdrošinātājiem ar konkrētu mērḳi, kas iekḷauj klientu finansiālo interešu aizsardzību.

Apdrošinātājam nav informācijas par apdrošināmajiem riskiem un apdrošināšanas objektu, pirms klients to nav sniedzis, tādējādi darījuma pusēm, slēdzot un pildot apdrošināšanas līgumu, pieejamā informācija ir asimetriska [27].

Tādēl, paredzot iespējamās problēmas, apdrošināšanas līgumiem tiek piemērots informācijas pilnīgas izpaušanas jeb vispārākās labās ticības princips, ko sauc par uberrimae fidei principu.

Šai ziṇā svarīgi ir apzināties, ka apdrošināšanas komersantam (apdrošinātājam), ar līgumu (komercdarijumu) uzṇemoties klienta riska finansiālās sekas, jāsaṇem atbilstoša atlīdzība par sniedzamajiem pakalpojumiem - to apdrošināšanas tiesībās sauc par apdrošināšanas prēmiju. Apdrošināšanas prēmijai jābūt noteiktai tādā apmērā, lai nodrošinātu līgumsaistību izpildi un nosegtu visus iespējamos apdrošinātāja izdevumus. Tādējādi apdrošinātājam jāspēj atbilstīgi novērtēt gan riska iestāšanās varbūtību, gan tā iespējamās sekas, un tieši klienta informācija tam ir primārais avots. Turklāt pašiem klientiem nebūtu izdevīgi, ka apdrošinātājs veiktu pirmslīguma pārbaudes, lai pārliecinātos par klienta sniegtās informācijas patiesumu un pilnīgumu, jo šādu pārbaužu izdevumi būtu jāsedz klientam papildus tiem izdevumiem, kas tieši attiecināmi uz risku segumu kā apdrošināšanas atlīdzības avotu.

Raksta mērḳis ir iepazīstināt lasītāju ar apdrošinājuma ṇēmēja un apdrošinātā informācijas atklāšanas pienākuma analīzi, ar šā pienākuma neizpildes civiltiesiskajām sekām, kā arī ieskicēt Latvijā pastāvošās problēmas saistībā ar to.

Pētījuma teorētiskā bāze ir Latvijas un citu valstu zinātnieku atzinumi par apdrošināšanas tiesībām, normatīvā bāze ir tiesiskais regulējums mūsu valstī. Raksta izstrādē tika izmantota analīzes un sintēzes metode, zinātniskās indukcijas un dedukcijas metode, kā arī novērošana.

\section{Apdrošināšanas līguma pušu mērḳi un pienākumi}

Apdrošināšana balstās uz sarežgitām līgumiska rakstura attiecībām starp apdrošinātāju, apdrošinājuma n̦ēmēju, apdrošināto un citiem apdrošināšanas līguma dalībniekiem, un tās mērḳis ir mazināt iespējamo nākotnes notikumu negatīvās finansiālās sekas, kaut arī visas iespējamās sekas apdrošinātais nevar novirzìt uz apdrošinātāju.

Apdrošināšanas attiecības balstās uz līgumu, kurā līdzēji ir pretējās puses. Tātad vienam līdzējam ir tiesības, otram attiecīgi - pienākumi.

Kaut arī sākotnēji liekas, ka apdrošināšanas līgums ir pavisam ỉpašs un no tā izrietošās attiecības nevar tikt apskatītas līdzīgi kā tās, kuras izriet no komercdarījuma, tomēr jāṇem vērā, ka pats apdrošinātājs ir komersants, un apdrošināšanas līgums nav un nevar būt kas cits kā komercdarījums, proti, līgums par pakalpojumu sniegšanu par atlīdzību (apdrošināšanas prēmiju). 
Protams, apdrošināšanas pakalpojums ir īpatnējs, tādēḷ apdrošināšanas līgumam tiek izvirzìtas papildu prasības, kas noteiktas ar imperatīvajām tiesību normām, vienlaikus ievērojot vispārējo darījumu brīvības principu.

Attiecībā uz līdzēju savstarpēju informācijas atklāšanu apdrošināšanas līgumam tiek izvirzītas nopietnākas prasības nekā lielākajai daḷai citu līgumu. Apdrošināšanas līgums pusēm uzliek saistības, kuras balstās uz labticību augstākajā pakāpē (uberrimae fidei), tomēr nekādā ziṇā nav tā, ka jebkuras apdrošināšanas attiecības tiek uzskatìtas par pilnīgi uzticamām savstarpējām attiecībām. Uberrimae fides princips apdrošināšanas attiecībās nepārveido līdzēju antagonistisko attiecību būtību un nevar arī tikt izmantots, lai nonāktu līdz uzticamām savstarpējām attiecībām, tomēr šis princips palīdz risināt svarīgus līdzēju resursu optimizācijas uzdevumus.

\section{Uberrimae fidei principa nozīme apdrošināšanas attiecībās}

Citās civiltiesību nozarēs nav tik izteikta pienākuma izpaust informāciju, kas varētu ietekmēt otra darījuma dalībnieka lēmumu noslēgt līgumu, kā tas ir apdrošināšanas tiesībās. Apdrošināšanas tiesībās šāds princips pastāv, un juridiskajā doktrīnā to apzīmē ar terminu latinnu valodā uberrimae fidei jeb vispārākajā labticībā. Noslēdzot apdrošināšanas līgumu, apdrošinājuma n̦ēmējam (dažos gadījumos arī apdrošinātajam) ir pienākums sniegt apdrošinātājam visas viṇu rīcībā esošās ziṇas par apdrošināmo risku. Šis princips atspoguḷots arī Latvijas tiesību doktrīnā. Uberrimae fidei principa būtỉbas skaidrojumu var atrast gan Latvijas tiesu praksē [9; 11], gan Eiropas Savienības Tiesas praksē - generāladvokātes Eleanoras Šarpstonas (Eleanor Sharpston) secinājumu 64. punktā lietā C-51/13 (Nationale-Nederlanden Levensverzekering Mij NV pret Hubertus Wilhelmus van Leeuwen) ir norāde, ka uberrimae fidei ir dažās ES tiesību sistēmās pastāvošais princips - generālklauzula vai nerakstìta valsts tiesību norma, kuru piemēro apdrošināšanas līgumiem, - tomēr tā specifiskā darbība un katrai darījuma pusei noteikto pienākumu skaidrības, precizitātes un paredzamības līmenis ir atkarīgs no iesaistītās konkrētās tiesỉbu sistēmas [12].

Pirmsākumā uberrimae fidei princips tika definēts vispārējās tiesībās, to piemērojot klienta sniegtajai informācijai apdrošināšanas līgumos, bet vēlāk tas attīstijās kā vispārējs apdrošināšanas tiesību princips [19].

Uberrimae fides princips nozīmē, ka apdrošināšanas līguma līdzējiem jārīkojas labticīgi, atklājot informāciju par visiem būtiskajiem faktiem saistībā ar apdrošināšanas piedāvājumu. Šis ir pretstats caveat emptor (piesardzības) principam, saskaṇā ar kuru pircējs nevar atgūt zaudējumus no pārdevēja par pirkuma objekta trūkumiem, ja vien pārdevējs nav apzināti slēpis defektus vai citādi sniedzis būtiskus maldinošus apgalvojumus [22, 79-132]. 
Vēsturiski pirmais informācijas atklāšanas principu apdrošināšanas līgumā definēja Mensfīldas grāfs (Lord Mansfield) 1766. gadā tiesvedībā Kārters pret Bēmu (Carter v Boehm):

"Apdrošināšana ir pieṇēmuma līgums. İpašus faktus, pēc kuriem var izskaitḷot nejaušỉbas risku, parasti zina tikai apdrošinātais: apdrošinātājs uzticas viṇa sniegtajām ziṇām un pieṇem, ka apdrošinātais neslēpj kādus viṇam zināmus apstākḷus, lai maldinātu apdrošinātāju, liekot tam domāt, ka šādu apstākḷu nav. Labticīgi nodomi nepiel̦auj, ka tiktu slēpti apstākḷi, kuri ir zināmi, tā, lai otra puse par tiem neuzzinātu un lai saṇemtu labumu no tā, ka otra puse tic pretējam." [29]

Uberrimae fides doktrīna attīstījās vispārējās tiesībās, attiecinot līdzvērtīgu labticības prasību uz apdrošinātāju. Šobrīd šis ir Eiropas Savienības tiesībās skaidri formulēts princips par pirmslīguma informācijas atklāšanu no abām līgumslēdzējām pusēm. Tã ir apdrošinātāja vai apdrošināšanas starpnieka sniedzamā informācija par darījuma pusi, kā arī apdrošināšanas produkta informācija, kurai šobrīd unificēti paredzēts speciālais noformējums un saturs, - tas noteikts ar Eiropas Parlamenta un Padomes 2016. gada 20. janvāra Direktīvu (ES) 2016/97 par apdrošināšanas izplatīšanu (pārstrādāta redakcija), un dokuments attiecas uz EEZ [4], savukārt Latvijas tiesībās tas ir îstenots ar Apdrošināšanas un pārapdrošināšanas izplatīšanas likumu.

Informācijas atklāšanas pienākums apdrošināšanas attiecībās nozīmē, ka apdrošinātajam ir jāatklāj precīzs objekta stāvoklis un riski, ko viṇš nodod apdrošinātājam, vienlaikus apdrošinātājam ir jāpārliecinās, ka potenciālais līgums atbilst apdrošinātā prasībām un vajadzībām, kā arī tas ir saṇēmis visu nepieciešamo informāciju, lai pieṇemtu lēmumu par līguma noslēgšanu.

\section{Atbildība par nepatiesas informācijas sniegšanu apdrošinātājam Latvijas tiesībās}

Apdrošināšanas līguma noslēgšanai ir nepieciešams, lai apdrošinātājs no klienta saṇemtu informāciju apdrošināmā riska izvērtēšanai. Tāpat apdrošinātājam jāzina par izmaiṇām klienta sniegtajā pirmslīguma informācijā. Savukārt klients ir atbildīgs par to, ka šì informācija ir patiesa un pilnīga.

Apzīmējums "klients" turpmāk tiks izmantots gan attiecībā uz apdrošinājuma ñēmēju, gan apdrošināto, jo informācijas sniegšanas pienākums apdrošinātājam ir attiecināms uz abiem nosauktajiem apdrošināšanas līguma dalībniekiem vienādi (Apdrošināšanas līguma likuma 23. panta ceturtā daḷa).

Apdrošināšanas līguma likuma, kā arī likuma "Par apdrošināšanas līgumu" (bija spēkā līdz 2018. gada 31. maijam, pirms stājās spēkā Apdrošināšanas līguma likums) normās paredzētas īpašas sekas par klienta informācijas atklāšanas pienākuma neizpildi - noslēgtā apdrošināšanas līguma spēkā neesamība, kā arī atbrīvojums apdrošinātājam no pienākuma izmaksāt apdrošināšanas atlīdzību, iestājoties apdrošinātajam riskam $[2 ; 6]$. 
Jel̦ena Alfejeva. Atbildība par nepatiesas informācijas sniegšanu

apdrošinātājam apdrošināšanas līguma ietvaros

Iepriekš arī Latvijas Republikas Augstākā tiesa atzina:

“[..] nav šaubu, ka apdrošinātājam, lai izvērtētu attiecīgā riska iespējamības pakāpi, ir būtiski zināt visus ar iespējamo risku saistītos apstākḷus gan pirms līguma noslēgšanas, gan tā darbības laikā. Likumā "Par apdrošināšanas līgumu" informācijas sniegšana par apdrošināto risku ir detalizēti reglamentēta, turklāt nodalot līgumslēdzēju tiesības un pienākumus pirms līguma noslēgšanas, tā noslēgšanas un darbības laikā, kā arī paredzot atšḳirīgas tiesiskās sekas šī pienākuma neizpildes gadījumā”. [7]

Apdrošināšanas līguma likuma 7. panta pirmajā dal̦ā ir iekḷauta norma par apdrošinājuma n,ēmēja un apdrošinātā pienākumu apdrošināšanas līguma noslēgšanas gadỉjumā sniegt apdrošinātāja pieprasito informāciju par apdrošināšanas objekta stāvokli un apstākḷiem, kas apdrošinātājam nepieciešama apdrošinātā riska iestāšanās iespējamības un iespējamā zaudējuma apmēra novērtēšanai, kā arī sniegt informāciju, kas attiecas uz apdrošinātā veselības stāvokli personu apdrošināšanā un ir nepieciešama, lai noslēgtu apdrošināšanas līgumu (iepriekš līdzīga norma bija iekḷauta arī likumā "Par apdrošināšanas līgumu”).

Lai pareizi piemērotu šo normu, ir jānoskaidro, kas ir tā informācija, kuru klientam ir pienākums sniegt apdrošinātājam.

N̦emot vērā minētajā pantā paredzēto (otrajā teikumā), apdrošinātājs riska iestāšanās iespējamības un iespējamā zaudējuma apmēra novērtēšanai izmanto arī publiski pieejamo vai savā rīcībā esošo tiesiski iegūtu informāciju par apdrošināšanas objekta stāvokli un apstākḷiem. Tas nozīmē, ka publiski pieejama vai apdrošinātāja rīcībā jau esoša informācija nebūtu iekḷaujama tajā informācijas klāstā, kā sniegšana ir klienta pienākums, ja vien apdrošinātājs neuzdod skaidru jautājumu, uz kuru gaida konkrētu atbildi.

Grūti noteikt, vai klients ir pienācīgi izpildījis informācijas atklāšanas pienākumu, atbildot noraidoši uz apdrošināšanas pieteikumā uzdoto vispārīgo aicinājumu sniegt informāciju par apstākḷiem, kuri var ietekmēt apdrošinātā riska iestāšanās iespējamību un iespējamā zaudējuma apmēra novērtēšanu, bet realitātē šādi apstākḷi ir bijuši. Klients nav riska izvērtēšanas speciālists, un, ja šādi apstākḷi nav bijuši acīmredzami, no klienta nevar prasìt tādu kompetenci risku izvērtēšanā, kāda ir pašam apdrošinātājam.

Tomēr par svarīgiem apstākḷiem, kas acīmredzami ietekmē apdrošināmo risku iestāšanos vai iespējamo zaudējuma apmēru, klientam nebūtu pamata informāciju noklusēt.

Tādēḷ ir jājautā, vai tiešām apdrošinātājam nepieciešams uzdot skaidru un nepārprotamu jautājumu, uz kuru tas gaida konkrētu atbildi, un klientam nav pienākuma papildus atklāt ko tādu, par ko nepārprotami skaidrs, ka tas ietekmē risku izvērtēšanu, kura jāveic apdrošinātājam.

Piemēram, Eiropas Vērtētāju asociāciju grupas TEGoVA grāmatas "Eiropas vērtēšanas standarti” sadaḷā "Apdrošināmās vērtības un bojājumu novērtēšana" norādīts:

"Apdrošināšanas līgums ir visaugstākās labticības pakāpes (uberrimae fidei) līgums.

Ir jāizpauž jebkādi faktori, kas, iespējams, varētu ietekmēt risku/-us (neatkarīgi no tā, vai šāda informācija tiek pieprasīta). Informācijas, kas varētu ietekmēt apdrošinātāja lēmumu nodrošināt segumu, nesniegšana var ḷaut tam atteikties no līguma." [18] 
Arī daḷa zinātnieku uzsver, ka apdrošinātajam svarīgi ir atklāt visu nepieciešamo informāciju pirms līguma noslēgšanas $[15 ; 16 ; 17 ; 24 ; 26]$.

Ja klienta rīcībā ir informācija, kas nepārprotami ietekmē apdrošināmo risku iestāšanās varbūtîbu vai iespējamo zaudējumu summu, klientam ir pienākums to atklāt apdrošinātājam pat tad, ja apdrošinātājs neuzdod par to konkrētu jautājumu.

Vai klientam, atbildot uz apdrošinātāja jautājumu nepareizi, var rasties negatīvas sekas (atbildība), ja šĩ informācija nekā neietekmēja slēdzamā apdrošināšanas līguma noteikumus? Lai to konstatētu, būtu jāveic analīze par konkrētā apdrošinātāja praksi apdrošināšanas līgumu noslēgšanā, un tas var būt visai sarežgitits uzdevums. Savukārt klienta pirmslīguma informācijas vispārējie kritēriji Latvijas apdrošināšanas tiesībās nav precīzi definēti.

Tāpēc var secināt, ka klienta pirmslīguma nepatiesas informācijas sniegšana ir jāanalizē individuāli, vispirms vērtējot atbildes uz precīzi uzdotiem jautājumiem. Ja kaut viena atbilde ir bijusi nepatiesa, jāizskata jautājums par negatīvām sekām.

Tomēr šīs negatīvās sekas nevar iestāties gadījumos, ja:

- klients ir maldīijies un šĩ maldība ir attaisnojama - tas korelē ar Apdrošināšanas līguma likuma normu par vainas pakāpēm par maldinošas informācijas sniegšanu, ko gan bieži jauc ar vispārējo klienta noskan,ojumu krāpties;

- informācija, kas nav bijusi patiesa, nav būtiska vai arī var konstatēt, ka tā nekādā veidā nav ietekmējusi slēdzamā apdrošināšanas līguma noteikumus - šajā gadījumā apdrošinātājs nebūs labticīgs, ja mēgeinās izmantot šādas informācijas sniegšanu kā pamatojumu atteikumam izmaksāt apdrošināšanas atlīdzību.

Informācijas būtiskuma vērtēšanā var tikt n̦emts vērā un pienācīgi interpretēts Latvijas Apdrošināšanas līguma likuma 7. panta pirmajā dạ̦ā lietotais vārds "nepieciešama", ja analīzei ir pieejami kritēriji, pēc kuriem apdrošinātājs vadās, nosakot līguma noteikumus un apdrošināšanas prēmiju. Protams, šeit ir arī kritēriji, kuri skaidri izriet no prakses, tomēr jebkurā gadījumā no apdrošinātāja būtu sagaidāma norāde uz šo kritēriju izmantošanu.

Savukārt atbildes vērtēšanā uz atklātu jautājumu par riska apstākḷiem būtu jāṇem vērā:

- vai informācija bijusi publiski pieejama, vai nepārprotami izsecināma no citiem apdrošinātājam zināmiem faktiem;

- vai informācija ir bijusi būtiska, vai tā varēja ietekmēt slēdzamā apdrošināšanas līguma noteikumus;

- vai klients zināja šo informāciju un bija spējīgs izvērtēt tās ietekmi uz slēdzamā apdrošināšanas līguma noteikumiem.

Neliekot akcentu uz informācijas būtiskumu, Apdrošināšanas līguma likumā nepatiesas informācijas sniegšanas gadijumi tiek škikiroti atkarībā no klienta vainas pakāpes. Jāpiemin, ka vaina var tikt vērtēta saistībā ar labticīgu rīcību [14]. 
Jel̦ena Alfejeva. Atbildība par nepatiesas informācijas sniegšanu apdrošinātājam apdrošināšanas līguma ietvaros

Apdrošināšanas līguma likuma 14. un 15. pantā ir noteikts, kādas tiesiskas sekas iestājas gadījumā, ja klients ir maldinājis apdrošinātāju, sniedzot pirmslīguma informāciju. Šai ziṇā likumdevējs konsekventi ievēro nosacījumu, ka šìs sekas nav diferencētas atkarībā no informācijas būtiskuma, bet tiek šḳirotas pēc klienta vainas pakāpes (Civillikuma 1640. pants) [2;3].

Ja maldinošu informāciju klients sniedzis vieglas neuzmanības dēl (Civillikuma 1646. pants), apdrošināšanas līgums paliek spēkā un apdrošinātājs var izvairīties no saistībām izmaksāt apdrošināšanas atlīdzību, kad iestājas apdrošinātais risks, tikai gadījumā, ja pierāda, ka, zinot pareizu informāciju, nekad līgumu nebūtu noslēdzis, turpretim nepatiesas informācijas sniegšana l̦aunā nolūkā vai rupjas neuzmanības dēl (Civillikuma 1641., 1645. pants) iznīcina apdrošināšanas līguma spēku, turklāt paredzot apdrošinātājam tiesības paturēt saskaṇā ar šo līgumu samaksāto apdrošināšanas prēmiju. L̦auns nolūks, rupja un viegla neuzmanība ir Civillikumā paredzētās vainas pakāpes, un tās ir atbilstoši jāinterpretē. [3]

Latvijas civiltiesību doktrīnā tiek pausts, ka civiltiesībās vainas jēdziens un tās konstatēšana ir saistīta ar objektīviem apstākḷiem, tāpēc ir grūti nošḳirt vainu no cita objektīvi konstatējama priekšnoteikuma - prettiesiskas rīcības [23]. Tomēr jebkuras vainas formas konstatēšana, runājot par personas juridisko atbildību, jāveic, vērtējot objektīvos apstākḷus, jo nav cita mehānisma cilvēka patieso nodomu konstatēšanai.

Turpretī ir arī uzskats, ka zaudējumu atlīdzības prasījuma pamatā par saistību (līgumisko) pārkāpumu ir Civillikuma 1779. pants, kurā vaina nav paredzēta kā atbildības priekšnoteikums, tomēr Civillikuma 1774. pantā, kas jāpiemēro kopā ar 1779. pantu, kā izṇēmums paredzēti nejauši notikumi jeb apstākḷi, par kuriem parādnieku nevar vainot, un tad arī kreditoram parādnieka vaina nav jāpierāda un parādnieks var atsvabināties no atbildības, pierādot vainas neesamību jeb to, ka saistības pārkāpums ir nejauša notikuma rezultāts [28, 12-15].

Civillikuma normas un atziņas par vainas pakāpēm saistot ar klienta nepatiesas informācijas sniegšanu apdrošināšanas līgumā, var secināt, ka būtu jāuzskata, ka klients ir sniedzis apdrošinātājam nepatiesu informāciju l̦aunā nolūkā vai rupjas neuzmanības dēḷ, ja viņš zināja pareizu atbildi uz jautājumu vai varēja to noskaidrot, tomēr atbildēja nepareizi.

Turklāt klientam l̦aunā nolūkā vai rupjas neuzmanības dēḷ (kas atbilstoši Civillikuma 1645. panta otrajai dạ̦ai civiltiesisko seku ziņā pielīdzināta l̦aunam nolūkam) maldinot apdrošinātāju, sekas ir pamatoti noteiktas kā apdrošināšanas līguma spēkā neesamība un apdrošināšanas prēmijas neatmaksāšana, jo tā ir nelabticība un Civillikuma 1. panta pārkāpums, kas jebkurā gadījumā ar apzinātu klienta rīcību apgrūtina apdrošinātājam līguma slēgšanas procesu.

Jautājums gan ir par vieglas neuzmanības saturu, proti, vai viegla neuzmanība būtu jākonstatē gadījumā, ja klients ir maldījies un šì maldība ir attaisnojama? Šeit îpaši ir izcel̦ams informācijas būtiskums, kuru pierādìt par pienākumu jāuzliek apdrošinātājam. Pierādījumu vērtēšana par to gan radītu sarežǵỉjumus tiesai, tomēr ir skaidrs, ka negatīvas sekas klientam no tās nevar iestāties, ja vien apdrošinātāja lēmums par līguma noslēgšanu 
bijis pieṇemts maldības ietekmē, kas saskaṇā ar Civillikumu būtu atzīstama par tādu, kas iznīcina līguma spēku. Ja ši informācija ietekmētu tikai cenas (apdrošināšanas prēmijas) noteikšanu, tā nebūtu jāṇem vērā, jo ticami pierādīt noteiktās apdrošināšanas prēmijas lielumu nav iespējams (prēmijas noteikšana ir apdrošinātāja vienpusēja, ārējai kontrolei nepakḷauta rīcība).

Apdrošināšanas līguma likuma 15. panta sestajā daḷā paredzētā proporcija nebūtu jān,em vērā, jo, pirmkārt, apdrošināšanas atlīdzība netiek noteikta proporcionāli no apdrošināšanas prēmijas un apdrošinātājs, iekasējot lielāku apdrošināšanas prēmiju, atlīdzību izmaksātu pilnā apmērā; otrkārt, ticami noskaidrot, cik liela prēmija tiktu noteikta, nav iespējams. Ši norma bija iekḷauta arī likumā "Par apdrošināšanas līgumu", bet nav zināmi gadỉjumi, kad tā būtu piemērota praksē.

Līguma izpildes problēma rodas arī gadījumā, ja ārējo apstākḷu maiṇa sāk būtiski ietekmēt līgumattiecības, tās neparedzēti pārveidojot. Lai gan līguma izpilde nav kḷuvusi neiespējama, jo tad varētu atsaukties uz nepārvaramu varu, tomēr tā, iespējams, kḷuvusi grūtāka un sāk neatbilst sākotnējam nodomam. Tādēḷ pamats, uz kura sākotnēji tika balstīts nodoms, var zust. Apstākḷu maiṇas ietekme uz līgumu var tikt mazināta ar netiešu nosacījumu, ka līgumslēdzējam ir tiesības izstāties no šỉ līguma, ja viṇš nekad nebūtu slēdzis šo līgumu izmainījušos apstākḷu situācijā [21, 60]. Šì doktrīna jau sen kḷuvusi pazīstama kā clausula rebus sic stantibus [13]. Apstākḷu maiṇa dažās jurisdikcijās arī vispārēji tiek atzìta par pamatu atkāpties no līguma, tomēr Latvijas tiesībās tā nav skaidri paredzèta.

Ekstrapolējot šo doktrīnu uz situāciju, kurā apdrošinātājs nesaṇem nepieciešamo informāciju pirms līguma noslēgšanas vai arī apstākḷi būtiski mainās līguma darbības laikā, būtu pareizāk noteikt, ka apdrošinātājam jābūt tiesībām atkāpties no šāda līguma, ja faktiskie tam nezināmie apstākḷi ir tādi, ka pilnīgas informācijas apstākḷos apdrošinātājs nebūtu noslēdzis apdrošināšanas līgumu [20,5-9]. Turklāt nebūtu pamatoti vērtēt, vai klients ir piel̦āvis pat vieglu neuzmanību, kas ir visai sarežgîts uzdevums.

Apdrošināšanas līguma likuma nosacījumus, kuri ir iekḷauti 15. panta septītajā daḷā un 20.-22. pantā, var uzskatīt par šîs doktrīnas realizāciju Latvijas apdrošināšanas tiesībās. Tomēr jāatzīmē, ka praksē nav zināmi šajos pantos noteiktās proporcionalitātes piemērošanas gadījumi, nav arī pamatojuma apgalvojumam, ka apdrošināšanas prēmija ir proporcionāli atkarīga no riska iestāšanās varbūtības un citiem šajās normās minētajiem apstākḷiem. Savukārt, ja apdrošinātājs noteikti atteiktos no līguma noslēgšanas, ja zinātu faktiskos apstākḷus (neatkarīgi no tā, vai klients ir vai nav pieḷāvis vieglu neuzmanību), apdrošinātājam būtu jāpieškirir tiesības atkāpties no līguma.

Runājot par klienta informācijas sniegšanu apdrošināšanas līguma darbības laikā (Apdrošināšanas līguma likuma 20. pants), vērtēšana log̣iski var tikt reducēta līdz ziṇojumam par izmaiṇām informācijā, kas tika sniegta, slēdzot līgumu. 
Jautājums ir par tādiem jauniem apstākḷiem, kas pasliktina situāciju ar risku iestāšanās varbūtību un par kuriem netika uzdots jautājums, līgumu slēdzot. Šie jaunie apstākḷi būtiski pārveido pirmslīguma situāciju. Šajā gadījumā analīze būtu veicama, ṇemot vērā jau iepriekš norādītos pirmslīguma informācijas vērtēšanas kritērijus.

Judikatūrā ir atrodamas atziṇas, ka klienta informācijas atklāšanas pienākuma saturs būtu noskaidrojams, tulkojot apdrošināšanas līguma noteikumus līguma saistību neizpildes vērtēšanā. Kaut arī atsaucei uz Civillikuma 1508. pantu būtu vajadzīgs detalizētāks skaidrojums par tā piemērošanu un to, kas strīdus attiecībās būtu atzīstams par parādnieku, kopumā var teikt, ka Augstākā tiesa lietā SKC-243/2017 pamatoti izvirza tēzi par apdrošināšanas noteikumu iztulkojumu par sliktu apdrošinātājam, cenšoties ar to pēc būtības labot likumdevēja paviršỉbu, neiekḷaujot šo nosacījumu apdrošināšanas attiecību tiesiskajā reglamentācijā [8]. Tādēl apdrošināšanas līguma noteikumu iztulkošana par sliktu apdrošinātājam ir jāiekḷauj likumā.

Jāuzsver, ka līguma noteikumu iztulkošana pretēji to jēgai nevar tikt veikta un paša informācijas sniegšanas pienākuma izpildes vērtēšanā būtu jāvadās pēc iepriekš minētā likuma regulējuma un jāizmanto šajā rakstā norādìtie kritēriji.

Atsevišḳi jāvērtē klienta pienākums sniegt patiesu informāciju par pieteikto apdrošināšanas gadījumu saskaṇā ar Apdrošināšanas līguma likuma 27. un 29. pantu (iepriekš likuma "Par apdrošināšanas līgumu" 21. un 22. pants). Latvijas tiesu praksē jau tika risināti jautājumi par klienta pienākuma neizpildi. Kaut arī likumdevējs nepatiesas informācijas sniegšanas sekas ir saistījis ar klienta vainas pakāpi (launs nolūks, rupja neuzmanība vai viegla neuzmanība), vairākos gadījumos tiesa neatzina pārkāpumu, konstatējot, ka nepatiesa informācija tika sniegta par kādu nebūtisku apstākli un neietekmēja pieteiktā gadījuma apstākḷ noskaidrošanu, nemaz nevērtējot klienta vainas pakāpi informācijas sniegšanā vai norādot, ka tieši informācijas nebūtiskums liecina par to, ka l̦auns nolūks vai rupja neuzmanība nav konstatējami.

Citkārt tiesa ir atzinusi, ka klients sniedzis apdrošinātājam nepatiesu informāciju, un tas atklāts, veicot negadijuma apstākḷu pārbaudi, kas ir likuma "Par apdrošināšanas līgumu" 21. panta pirmās dạlas pārkāpums. Šo atziṇu ir akceptējusi arī Latvijas Republikas Augstākā tiesa, izskatot lietu kasācijas kārtībā [10].

Nav gadijumu, kuros tiesa piemērotu likuma "Par apdrošināšanas līgumu" 22. panta otro daḷu, nosakot vai atzīstot par pamatotu apdrošināšanas atlīdzības samazinājumu vieglas neuzmanības gadỉjumā, vai arī tādu, kuros par to būtu strīds. Tādējādi Apdrošināšanas līguma likuma 29. panta otrās daḷas regulējums nav aktuāls.

Ja klients apdrošinātājam sniedz nepatiesu informāciju, lai nepamatoti gūtu labumu no apdrošināšanas atlīdzības, par to paredzēta kriminālatbildība. Šādas klienta darbības ir noziedzịgs nodarījums saskaṇā ar Krimināllikuma 177. un 178. pantu. [5]

Interesanti, ka par nepatiesu ziṇu sniegšanu, noslēdzot apdrošināšanas līgumu, apdrošinājuma ņēmējam paredzēta administratīvā atbildība. Latvijas Administratīvo pārkāpumu kodeksa 166.8 pantā par fiktīvu ziṇu sniegšanu, veicot mantas obligāto 
apdrošināšanu, noteikts, ka izsaka brīdinājumu vai uzliek naudas sodu līdz septiṇdesmit eiro. Tomēr šis pants praksē nevar tikt piemērots, jo Latvijas tiesībās nav paredzēta obligātā apdrošināšana, kuras objekts būtu manta. [1]

Nepilnības krimināltiesiskajā un administratīvo pārkāpumu regulējumā šeit detalizētāk netiks apskatītas specifisko iezīmju un raksta apjoma ierobežojuma dēḷ.

Veiktās analīzes rezultātā var secināt, ka klienta informācijas izpaušanas princips apdrošināšanas attiecībās prasa pareizu interpretāciju saskaṇā ar mērḳiem, kā arī tiesiskajā regulējumā par to būtu jāveic korekcijas.

\section{Nobeigums}

Klienta informācijas izpaušanas pienākums apdrošināšanas līgumos atbilst apdrošināšanas līguma dabai un palīdz noslēgt apdrošināšanas līgumu, optimizējot līguma slēgšanas izdevumus par labu klientam. Arī šã pienākuma izpildes vērtēšana, ciktāl nav konstatējams l̦auns klienta nolūks vai rupja neuzmanība, jāveic atbilstoši apdrošinātāja iespējām izvērtēt riskus un noteikt apdrošināšanas līguma noteikumus.

Nosakot tiesiskās sekas, ja klients pārkāpj informācijas izpaušanas pienākumu vieglas neuzmanības dēl, būtu jāvērtē informācijas būtiskums, lai apdrošinātājs izlemtu jautājumu par līguma noslēgšanu.

Uberrimae fidei doktrīnas pamatojums izriet no fakta, ka apdrošināšanas līgums prasa no klienta zināmu labticību un godīgumu, lai apdrošinātājam būtu iespēja pilnībā izprast apdrošināšanas objektu, ar to saistitos riskus un noteikt par to atbilstošu samaksu.

Kaut arī Latvijas Apdrošināšanas līguma likumā ir paredzēts informācijas izpaušanas pienākums, tomēr nav atklāts tā mērḳis, tādēḷ tiesu praksē ir radušās grūtības veikt mērḳim atbilstošu klienta uzvedības vērtēšanu un tiesību normu attiecināšanu uz to. Tāpat nav skaidrs un bez piemērošanas praksē palicis regulējums par sekām klienta informācijas pienākuma pārkāpšanas gadījumā vieglas neuzmanības dēll.

Atbilstīgi secinātajam var piedāvāt tiesību normu grozỉjumu priekšlikumus.

1. Izteikt Apdrošināšanas līguma likuma 8. panta pirmo dạı šãdi: "(1) Apdrošināšanas līguma noteikumiem jābūt skaidriem un saprotamiem. Priekšroka dodama tādam apdrošināšanas līguma noteikumu iztulkojumam pret citiem, kurš visvairāk saista apdrošinātāju."

2. Mainīt Apdrošināšanas līguma likuma 15. panta nosaukumu uz "Apdrošināšanas līguma noslēgšana, apdrošinātājam nesaņemot tam nepieciešamo informāciju".

3. Svītrot Apdrošināšanas līguma likuma 15. panta sesto dalıu.

4. Izteikt Apdrošināšanas līguma likuma 22. panta septīto dal̦u šādi: "(7) Apdrošinātājs izmaksā apdrošināšanas līgumā paredzēto apdrošināšanas atlīdzību, ja apdrošināšanas gadījums iestājas pirms apdrošināšanas līguma noteikumu grozišanas vai pirms tā izbeigšanas un apdrošinājuma ṇēmējs vai apdrošinātais nav izpildījis šā likuma 20. pantā noteiktās prasības, izṇemot:

1) ja tas ir noticis ar apdrošinājuma ṇēmēja vai apdrošinātā l̦aunu nolūku vai rupjas neuzmanības dēḷ; 
2) ja apdrošinātājs pierāda, ka tas nekādā gadījumā nebūtu noslēdzis apdrošināšanas līgumu, ja būtu zinājis par apdrošinātā riska iestāšanās iespējamības un iespējamā zaudējumu apmēra novērtēšanas faktiskajiem apstākḷiem, kuri atklājušies, iestājoties apdrošināšanas gadījumam; šādā gadījumā apdrošināšanas atlīdzība nedrīkst pārsniegt iemaksāto apdrošināšanas prēmiju."

5. Izteikt Apdrošināšanas līguma likuma 29. panta otro dalı šādi: "(2) Ja apdrošinājuma ñēmējs, apdrošinātais vai labuma guvējs vieglas neuzmanības dēl nav izpildījis kādu no šā likuma 27. pantā noteiktajiem pienākumiem, apdrošinātājs ir tiesīgs atteikties izmaksāt apdrošināšanas atlīdzību tikai gadījumā, ja šā pienākuma neizpildes rezultātā kḷuva neiespējams ticami nodibināt, vai pieteiktais gadījums ir vai nav atzīstams par apdrošināšanas gadījumu."

\section{Responsibility for Providing False Information to Insurance Contract}

\section{Abstract}

This article discusses the responsibility for providing false information to insurer in insurance contract in Latvian insurance law. The author of the article first gives an overview of the objectives and obligations of the parties of the insurance contract, describing the nature of the insurance contract for understanding what the reason is why insurers should receive information about an insurable object and risks prior to the insurance case. The importance of uberrimae fidei principle in insurance relations is also discussed. The article further discusses issues of determining liability and consequences of false information. The article concludes with a brief summary of solutions for improving regulation of insurance relations in Latvia related to the problems discussed.

The study has been mainly based on the analysis and synthesis method, scientific induction and deduction methods, comparative method, and observation.

Keywords: insurance contract, uberrimae fidei, contract responsibility.

\section{Avotu un literatūras saraksts}

\section{Tiesību akti}

1. Administratīvo pārkāpumu kodekss: Latvijas Republikas likums: stājies spēkā 01.07.1985. Latvijas Padomju Sociālistiskās Republikas Augstākās Padomes un Valdības Ziñotājs. 51, 20.12.1984. Iegūts no: https://likumi.lv/doc.php?id=89648 [sk. 29.03.2019.].

2. Apdrošināšanas līguma likums: Latvijas Republikas likums: stājies spēkā 01.06.2018. Latvijas Vëstnesis. 97(6183), 15.05.2018. Iegüts no: https://likumi.lv/ta/id/299053-apdrosinasanas-ligumalikums [sk. 03.03.2019.]. 
Jel̦ena Alfejeva. Atbildība par nepatiesas informācijas sniegšanu

apdrošinātājam apdrošināšanas līguma ietvaros

3. Civillikums: Latvijas Republikas likums: stājies spēkā 01.09.1992. Valdības Vēstnesis, 41, 20.02.1937. Iegūts no: https://likumi.lv/doc.php?id=225418 [sk. 08.03.2019.].

4. Eiropas Parlamenta un Padomes 2016. gada 20. janvāra Direktīva (ES) 2016/97 par apdrošināšanas izplatīšanu (pārstrādāta redakcija): starptautisks dokuments. Eiropas Savienības Oficiālais Vèstnesis. L 26/19, 02.02.2016.

5. Krimināllikums: Latvijas Republikas likums: stājies spēkā 01.04.1999. Latvijas Vēstnesis. 199/200(1260/1261), 08.07.1998. Iegūts no: https://likumi.lv/doc.php?id=88966 [sk. 30.03.2019.].

6. Par apdrošināšanas līgumu: Latvijas Republikas likums: stājies spēkā 01.09.1998., zaudējis spēku 01.06.2018. Latvijas Vēstnesis. 188/189(1249/1250), 30.06.1998. Iegūts no: https://likumi.lv/doc. php?id=48896 [sk. 03.03.2019.].

\section{Tiesu prakse}

7. Augstākās tiesas Civillietu departamenta 2015. gada 24. septembra spriedums lietā Nr. C27190010, SKC-116/2015.

8. Augstākās tiesas Civillietu departamenta 2017. gada 4. jūlija spriedums lietā Nr. C30683713 SKC-243/2017.

9. Augstākās tiesas Civillietu departamenta 2017. gada 22. decembra spriedums lietā Nr. C30711611 SKC-278/2017.

10. Augstākās tiesas Civillietu departamenta 2018. gada 28. marta spriedums lietā Nr. C30419915 SKC-75/2018.

11. Augstākās tiesas Senāta Civillietu departamenta 2013. gada 12. jūnija spriedums lietā Nr. SKC-43/2013.

12. G̦enerāladvokātes Eleanoras Šarpstones (Eleanor Sharpsgton) secinājumi, sniegti 2014. gada 12. jūnijā lietā C-51/13 Nationale-Nederlanden Levensverzekering Mij NV pret Hubertus Wilhelmus van Leeuwen. Iegūts no: http://curia.europa.eu/juris/document/document_print.jsf; jsessionid=9ea7d2dc30d5b8a88f0af8724495958ac8a27ef5c6e1.e34KaxiLc3qMb40Rch0SaxyLa hf0?doclang=LV\&text=\&pageIndex=0\&docid=153606\&cid=166347 [sk. 30.03.2019.] .

\section{Literatūra}

13. Abas, P. 1989. Rebus sic stantibus. Deventer: Kluwer.

14. Beatson, J., Friedmann, D. 1995. Good faith and fault in contact law. Clarendon Press.

15. Burling, J., Lazarus, K. 2012. Research Handbook on International Insurance Law and Regulation. Edward Elgar Publishing. Iegūts no: https://EconPapers.repec.org/RePEc:elg:eebook:14215 [sk. 22.01.2019.].

16. Dixit, A. 2000. Adverse Selection and Insurance with Uberrima Fides, in Incentives, Organization, and Public Economics: Essays in Honor of Sir James Mirrlees. Eds. Peter J. Hammond and Gareth D. Myles. Oxford: Oxford University Press.

17. Dixit, A., Picard, P. 2003. On the Role of Good Faith in Insurance Contracting. In: Economics for an imperfect world: Essays in honor of Joseph E. Stiglitz. Cambridge and London: MIT Press.

18. Eiropas vērtēšanas standarti: astotā redakcija. Eiropas Vērtētāju asociāciju grupa TEGoVA. 2016. Iegūts no: https://www.vertetaji.lv/upload/rev/evs_2016_lv_darba.doc [sk. 01.04.2019.].

19. Heiss, H., Lakhan, M. 2011. Principles of European Insurance Contract Law: A Model Optional Instrument With a Postscript in Honour of Fritz Reichert-Facilides. Project Group Restatement of European Insurance Contract Law Extent. Universität Insbruck. Iegūts no: www.restatement. info [sk.12.01.2019.]. 
Jeḷena Alfejeva. Atbildỉba par nepatiesas informācijas sniegšanu apdrošinātājam apdrošināšanas līguma ietvaros

20. Hondius, E., Grigoleit, C. 2011. Unexpected Circumstances in European Contract Law. The Common Core of European Private Law. Cambridge University Press.

21. Hutchison, A. 2009. Change of Circumstance in Contract Law: The Clausula Rebus sic Stantibus. Journal of Contemporary Roman Dutch Law. 72, 60-73.

22. Johnson, A. M. 2008. An economic analysis of the duty to disclose information: Lessons learned from the caveat emptor doctrine. San Diego Law Review. 45, 79-132.

23. Kārkliṇš, J. 2006. Latvijas līgumtiesību modernizācijas galvenie virzieni. Promocijas darba kopsavilkums juridisko zinātṇu doktora zinātniskā grāda iegūšanai. Rīga: Latvijas Universitāte. Iegūts no: https://dspace.lu.lv/dspace/bitstream/handle/7/290/Karklins_J_Latvijas_ligumtiesibu_modernizacijas_2006_Kopsav_LV.pdf?sequence=2 [sk. 22.01.2019.].

24. Lowry, J., Rawlings, P., Merkin, R. 2011. Insurance Law: Doctrines and Principles. 3rd ed. Hart Publishing.

25. Mantrovs, V. 2018. Apdrošināšanas atlīdzības izmaksas atteikuma regulējums Latvijā. Latvijas Universitātes 76. starptautiskās zinātniskās konferences rakstu krājums. Latvijas Universitāte. Iegūts no: https://www.lu.lv/fileadmin/user_upload/lu_portal/apgads/izdevumi/2018/Book_76_ juristu_konference_2018_-gala.pdf [sk. 22.01.2019.].

26. Rothschild, M., Stiglitz, J. 1976. Equilibrium in Competitive Insurance Markets: An Essay on the Economics of Imperfect Information. Quarterly Journal of Economics. 90, 629-649.

27. Strauss, J. D. 2008. Uberrimae Fidei and Adverse Selection: the Equitable Legal Judgment of Insurance Contracts. MPRA. Iegūts no: http://mpra.ub.uni-muenchen.de/10874/1/_Strauss_ Utmost_Good_Faith_and_Adverse_Selection_Equitable_Legal_Judgment_of_Insurance_ Contracts.pdf [sk. 29.01.2019.].

28. Strazdiṇš, G̦. 2018. Vispārējais zaudējumu atlīdzības prasījuma pamats delikta un saistības pārkāpuma gadījumā. Jurista Vārds. 06.02.2018., 6(1012), 12.-15.

29. Watterson, S. 2008. Carter v Boehm (1766). In: Landmark cases in the law of contract. Mitchell Charles and Mitchell Paul eds. Hart Publishing. 